\title{
Investment attractiveness of energy saving measures
}

\author{
Arsen Tleppayev ${ }^{1, *}$, and Assel Azhibayeva ${ }^{2}$ \\ ${ }^{1}$ Department of economics and entrepreneurship, Kazakh-German University, 111 Pushkin, Almaty, Kazakhstan \\ ${ }^{2}$ Department of economics and entrepreneurship, Kazakh-German University, 111 Pushkin, Almaty, Kazakhstan
}

\begin{abstract}
The problem of energy efficiency of buildings is especially relevant in Kazakhstan. According to the state policy of innovative development of national economy, in recent decades, it has been necessary to solve the problems of saving energy resources, introducing renewable energy technologies and increasing energy efficiency. One of the most important issues of energy saving and energy efficiency is the problem of sustainable functioning and innovative development of housing and communal services in Kazakhstan, which is directly related to the modernization of residential buildings in order to reduce operating costs and improve energy efficiency. Analysis and study of economic approaches to financing energy efficiency measures are especially important in the framework of almost implemented projects for the modernization of housing and communal services.
\end{abstract}

\section{Introduction}

The housing sector of the Republic of Kazakhstan is the 3rd largest consumer of electricity and heat after the energy and production sectors. In this sector, there are significant reserves for energy conservation and energy saving, in parallel, there is potential for the development and implementation of energy saving measures based on investments and long-term investments in the modernization of the entire industry.

It should be noted that housing and communal services are the most ineffective and costly in terms of energy consumption. This sector has very significant reserves of energy conservation and energy saving, thereafter, there is a huge potential and ample opportunities for the development and implementation of energy-saving measures based on placing of funds and long-term investments in the modernization of the entire industry.

Most of the buildings in Kazakhstan were built during the period from 1950 to 1980 of the last century and do not meet modern thermal insulation requirements, which leads to an overestimation of the energy intensity of resources and significant heat losses, therefore this housing stock requires deep modernization. Instead of replacing or repairing particular engineering systems, it is necessary to develop and put forward a list of specific energy saving measures in the form of integrated solutions that allow obtaining a high level of energy efficiency after modernization or reconstruction of houses.

The reasons for the slow introduction of new effective technologies can be identified, the main of which are:
- insufficient funding, since such programs are quite costly to implement and they require identifying additional sources of funding;

- poor support for energy efficiency programs from the state and regional authorities;

- insufficient investment incentives for private business participation in the development and implementation of energy efficient technologies.

Experience shows that with heat supply of $2 / 3$ of the buildings and structures in operation, there is a very high level of standard costs, and excess losses can be observed with some of them, which in turn negatively affect the profitability of energy efficient measures and increase the investment attractiveness of the housing and communal sector of a country as a whole. Thus, the issue of attracting investments in energy saving is a key factor in improving the quality and availability of energy saving measures for all subjects of the housing and communal sector associated with their technological modernization and increasing investment attractiveness, which, in turn, are the main factors in reforming the housing and communal services.

There are a number of problems in the development and implementation of measures to save energy and improve the energy efficiency of residential buildings:

- a high level of depreciation of fixed assets, since most of the apartment buildings were built in the period before 1980, and they do not correspond to the modern parameters of energy efficiency of buildings, which causes significant heat losses;

- low degree of equipment and uneven provision of housing stock with whole-building meters;

- lack of effective financial instruments to improve the energy efficiency of buildings;

- low investment attractiveness of housing and communal services;

\footnotetext{
*Corresponding author: arsentlp@gmail.com
} 
- low tariffs in the field of heating supply of residential buildings;

- the mechanism for the implementation of publicprivate partnership projects in the field of energy saving has not been developed;

- the need to improve the regulatory framework in the field of energy efficiency.

Now therefore, the issue of attracting investments in energy saving is a key factor in improving the quality and availability of energy-saving measures for all subjects of housing and communal services related to their technological modernization and increasing investment attractiveness, which, in turn, is a determining factor in reforming housing and communal services.

However, the main issue when deciding on the allocation of funds for modernization or renovation is the issue of obtaining an economic effect from the implementation of these measures and the economic efficiency of investments.

\section{Literature review}

The main issue in deciding on the allocation of funds for modernization or renovation is a matter of getting the economic effect of the implementation of these measures and the cost-effectiveness of investments. Financial indicators to assess the construction of buildings are described in the optimal value of the concept (methodology optimal value), which has been widely used since the adoption of Directive 2010/31 / EC on the energy performance of buildings. This methodology is discussed in various studies: Araujo et al. (2016), Ascione et al. (2016), Atanasiu et al. (2013), Ballarini et al. (2017), Becchio et al. (2015), Hamdy et al. (2017), Haase et al. (2015), Enseling and Loga (2013), Leutgöb and Rammerstorfer (2013), Ortiz et al. (2016), Pikas et al. (2015), Tadeu et al. (2016) [1-11].

According to L.N. Danilevsky "The main economic indicator of the effectiveness of investments can serve as a full extra income that can be obtained for the life of the energy-saving measures in view of building an interestbearing intermediate proceeds from the sale event, i.e. the accrued income." [12].

According to O.D. Maksimchuk "Energy efficiency is determined by the ratio of savings/profit from the introduction of energy-saving, including innovative technologies, and the implementation of energy-saving measures that resulted in these effects." [13].

O.S. Golubova methodology discloses a method for assessing economic efficiency of measures to improve the energy efficiency of residential buildings, on the example of the conditions and regulatory legal acts of the Republic of Belarus [14].

According to the developed methodology, the algorithm for assessing the economic efficiency of measures to improve the energy efficiency of residential buildings should include four main stages.

The first stage includes:
- determination of the settlement horizon, i.e. for what time period is it possible to plan investments and assess economic efficiency;

- the necessary list and schedule of measures for the reconstruction of the object are developed, taking into account the technologies and equipment used;

- the timing of activities and operational periods of use of all equipment are planned;

- the number and periods of maintenance, repair or replacement of technological equipment are calculated according to the terms of their use.

The second stage involves planning one-off capital investment in the costs of:

- purchase, installation and commissioning of technological equipment;

- preparation of design specifications and estimations;

- construction and installation works.

The third stage includes the estimated part of the project, where the current net cash flows are calculated and future revenues from energy savings are predicted after the implementation of energy efficient measures, taking into account the costs of operating the facility and equipment during the period of regular operation. The level of costs for the consumption of energy resources received from external energy suppliers is determined, and the change in tariffs for consumed energy resources is also given consideration when calculating the resulting savings after increasing the energy efficiency of the facility. The capital costs for equipment maintenance and the purchase of the necessary consumables for operation and maintenance are calculated.

The fourth stage includes the calculation of an objective assessment of the economic effect of the implementation of energy efficiency measures by comparing the current net cash flows with the level of capital investments, keeping in mind the discount factors, including the total amount of one-time capital costs for the installation of technological equipment and the estimate of discounted cash flows for the period under review.

The survey results show that many of the existing methods for evaluating the cost-effectiveness of measures to improve energy efficiency of residential buildings are based on the methods of evaluation of investment projects. Since any energy efficiency measures require financial investment, they can be viewed as an investment project. Therefore, the calculation of the efficiency of the investment project is carried out, which should take into account the following: the influence of the cost of money over time, opportunity costs; possible changes in project parameters; calculations based on the actual cash flow rather than accounting indicators, inflation, the risk associated with the project. In preference it is proposed to calculate the generally accepted indicators for assessing the effectiveness of an investment project: NPV, ARR, PP, DPP and other dynamic indicators.

Note that the analysis of existing methods confirms the absence of universal recommended energy saving measures for buildings fundamentally different usage 
mode, which indicates the need for complex tools of economic benefit and performance evaluation.

\section{Results}

According to the Committee on Statistics of the Republic of Kazakhstan, the housing stock of the Republic of Kazakhstan is 364311.7 thousand $\mathrm{m} 2$ of total area, of which 182985.1 thousand $\mathrm{m} 2$ belongs to block of flats, which is $50.2 \%$ of the total housing stock. [15]

Figure 1 shows a diagram of the proportional ratio of types of apartment buildings according to the materials of the outer walls.

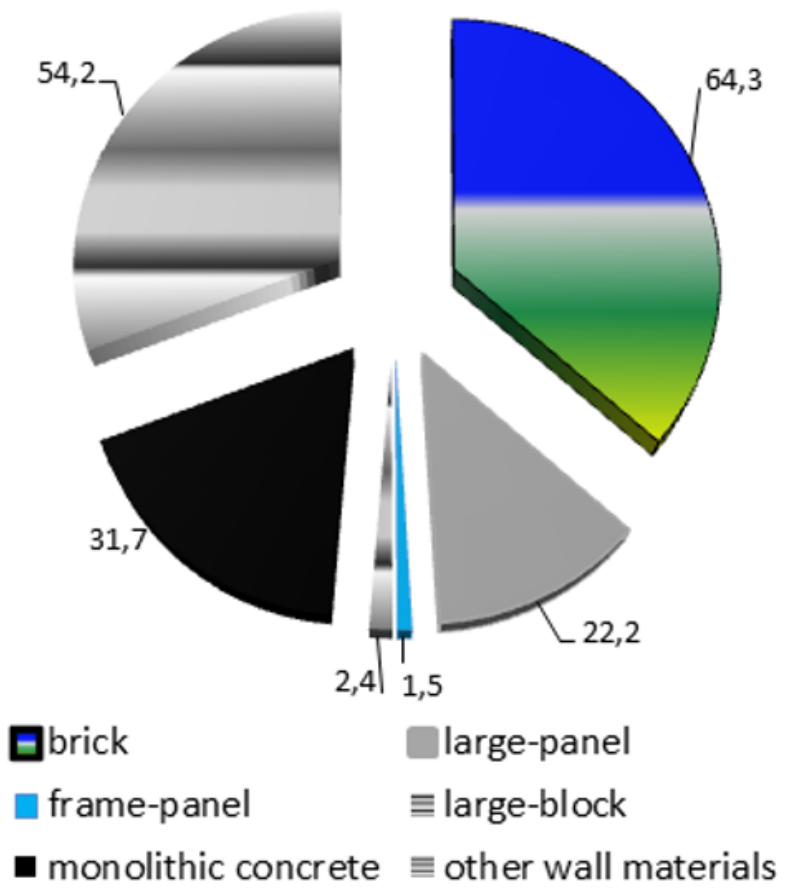

Fig. 1.Characteristics of apartment buildings by wall materials, area in million $\mathrm{m} 2$ according National Statistics.

A significant part of the housing sector is made up of block of flats with centralized heat and electricity supply. About $40 \%$ of the area of residential buildings was built before 1980 and they do not meet modern requirements for thermal insulation, which results in significant heat loss.

Many residential buildings are in need of various types of repair (repair of facades, roofs, wall panels seals, etc.), and $1,449.0$ thousand $\mathrm{m} 2$ or $0.4 \%$ of the total area of the housing stock is in disrepair and requires demolition as unfit for further use.

The need for action is noted in the direction of improving methods for assessing buildings from the point of view of the efficiency of using incoming heat energy. Energy performance certification, which provides a basis for assessing and comparing the energy consumption of different buildings, is believed to be one of the best methods. This instrument can also create the basis for financial incentives, and obtaining an energy efficiency class will create preconditions for the design of newly erected energy-efficient buildings and the modernization of existing ones.
A typical 5-storey building built in 1970-1990 has been taken for the assessment. A 5-storey residential building, under examination, is of rectangular shape in plan with dimensions of sides $34.20 \times 12.00 \mathrm{~m}$, according to the typological criterion belongs to the slab block of flat. The residential section (block section) is a cell consisting of several apartments located around one communication node (an entrance, a tambour, and a stairway). The layout of the area of each apartment is made in accordance with the functional diagram of the interconnection of the premises. In the projected house, the type of staircase is cross-cut. According to operational requirements, the designed residential building belongs to the II degree of durability.

The main functional solutions of the building: a different number of living rooms (one-, two-, three-room apartments) with utility rooms are on each floor of the building: an entrance hall, a kitchen, a toilet and a bathroom (combined for one-room apartments). Project space-planning decisions of the residential building are made in accordance with the current state norms, rules and standards, and sanitary norms. Layout concept of the apartments is made in accordance with the fire safety and public health requirements, ergonomic and environmental demands.

With reference to the normative and technical characteristics, building energy certificates of a residential five-storeyed brick building without and with insulation have been developed. Heat energy consumption for the heating season before insulation was $318621.9 \mathrm{kWh} / \mathrm{year}$, and total heat loss of the building for the heating period was $391,841.1 \mathrm{kWh} /$ year. After energy saving measures, these indicators are 121309 and $184783 \mathrm{kWh}$ /year, respectively.

Consequently, as a result of measures for the insulation of external structures, the consumption of thermal energy during the heating period has been decreased to $197312.9 \mathrm{kWh} / \mathrm{year}$, i.e. there is a $60 \%$ reduction. The total heat loss of the building has been decreased to $207,058.1 \mathrm{kWh} /$ year, representing a $47 \%$ reduction, which indicates the efficiency of the energysaving measures.

As a result of the study, the following recommendations have been made:

- first, to treat energy efficiency measures as an investment project that requires funding;

- secondly, to use thermal modernization with the installation of energy-efficient panels Penoplex as a measure to improve the energy efficiency of residential buildings;

- thirdly, there is a need to use additional measures in combination to obtain a synergistic effect.

Thermal modernization means insulation of external facade walls, attic and basement floors.

Thermal panels with a thickness of $10 \mathrm{~mm}$ have been selected for thermal modernization. The total amount of expenses required for the thermal modernization of a five-storeyed block of flat without buying a buildinglevel heat meter is $16,042,506$ tenge, consequently with a building-level heat meter, it is 16,602,506 tenge.

Timing of the projected payback period is carried out on the basis of the "Methodology for calculating the 
predicted payback period for investments aimed at insulating facades of residential and public buildings", developed under the United Nations Development Program (UNDP) Project and the Global Environment Facility (GEF) [16].

The total capital costs for the insulation of the outer walls of a residential house without installation of a building-level heat meter are amounted to 16,042,506 tenge, with installation it is 16,602,506 tenge. The calculation of operating costs is carried out before and after insulation, as well as with the installation of a building-level heat meter and without installation.

Operating costs, taking into account the loss of heat energy through $1 \mathrm{~m}^{2}$ of the outer wall for one heating season before insulation without installing a buildinglevel heat meter are 490,9 tenge.

Operating costs, taking into account the loss of heat energy through $1 \mathrm{~m} 2$ of the outer wall for one heating season after renovation without installing a buildinglevel heat meter are 102,02 tenge.

Operating costs, taking into account the loss of heat energy through $1 \mathrm{~m} 2$ of the outer wall for one heating season after renovation with the installation of a building-level heat meter are 76,9 tenge.

Calculations of the payback of energy saving measures have been performed within the framework of the study. We will make calculations considering the following indicators:

- capital costs for additional insulation of $1 \mathrm{~m}^{2}$ of an external wall without installing a building-level house meter, in tenge;

- capital costs for additional insulation of $1 \mathrm{~m}^{2}$ of an external wall with installing a building-level house meter, in tenge;

- operating costs, considering the loss of heat energy through $1 \mathrm{~m}^{2}$ of the outer wall for one heating season before insulation without installing a building-level heat meter, in tenge $/ \mathrm{m}^{2}$ per year;

- operating costs, considering the loss of heat energy through $1 \mathrm{~m}^{2}$ of the outer wall for one heating season before insulation with installing a building-level heat meter, in tenge $/ \mathrm{m}^{2}$ per year (table 1 ).
Table 1.Investment indicators.

\begin{tabular}{|c|c|c|}
\hline Characteristics & Designation & Value \\
\hline $\begin{array}{l}\text { Capital costs for the } \\
\text { construction of } 1 \mathrm{~m}^{2} \text { of an } \\
\text { external wall without } \\
\text { installing a building-level } \\
\text { house meter, in tenge }\end{array}$ & $\mathrm{C}_{1}$ & 8431 \\
\hline $\begin{array}{l}\text { Capital costs for the } \\
\text { construction of } 1 \mathrm{~m}^{2} \text { of an } \\
\text { external wall with the } \\
\text { installation of a building- } \\
\text { level heat meter, in tenge }\end{array}$ & $\mathrm{C}_{2}$ & 8725 \\
\hline $\begin{array}{l}\text { Operating costs, } \\
\text { considering the loss of heat } \\
\text { energy through } 1 \mathrm{~m}^{2} \text { of the } \\
\text { outer wall for one heating } \\
\text { season before renovation } \\
\text { without installing a } \\
\text { building-level heat meter, } \\
\text { in tenge }\end{array}$ & $\mathrm{O}_{1}$ & 490,9 \\
\hline $\begin{array}{l}\text { Operating costs, } \\
\text { considering the loss of heat } \\
\text { energy through } 1 \mathrm{~m}^{2} \text { of the } \\
\text { outer wall for one heating } \\
\text { season after renovation } \\
\text { without installing a } \\
\text { building-level heat meter, } \\
\text { in tenge }\end{array}$ & $\mathrm{O}_{2}$ & 105,02 \\
\hline $\begin{array}{l}\text { Operating costs, } \\
\text { considering the loss of heat } \\
\text { energy through } 1 \mathrm{~m}^{2} \text { of the } \\
\text { outer wall for one heating } \\
\text { season after renovation } \\
\text { with the installation of a } \\
\text { building-level heat meter }\end{array}$ & $\mathrm{O}_{2 \text { (heat meter) }}$ & 76,9 \\
\hline $\begin{array}{l}\text { The difference in heat } \\
\text { energy losses through } 1 \mathrm{~m}^{2} \\
\text { of the outer wall before } \\
\text { carrying out measures to } \\
\text { insulate the facades of an } \\
\text { existing building }\left(\mathrm{O}_{1}\right) \text { and } \\
\text { after insulation }\left(\mathrm{O}_{2}\right) \text { without } \\
\text { a heat meter, in tenge }\end{array}$ & $\Delta \mathrm{O}$ & 385,95 \\
\hline $\begin{array}{l}\text { The difference in heat } \\
\text { energy losses through } 1 \mathrm{~m}^{2} \\
\text { of the outer wall before } \\
\text { carrying out measures to } \\
\text { insulate the facades of an } \\
\text { existing building }\left(\mathrm{O}_{1}\right) \text { and } \\
\text { after insulation }\left(\mathrm{O}_{2}\right) \text { with a } \\
\text { heat meter, in tenge }\end{array}$ & $\Delta \mathrm{O}_{\text {heat meter }}$ & 414 \\
\hline
\end{tabular}

The methodology for calculating the payback period consists of the following stages:

- to decide whether a residential building renovation project is financed by from own or borrowed funds.

- if a decision is made to use borrowed funds, it is necessary to determine the terms of the loan (deadline, interest rate, number of payments, etc.)

- payback period calculation for different conditions

According to this method, heat tariffs are increasing annually. This means that the annual savings in money will increase with each subsequent year (heating season).

It should be noted that in this case of facade insulation, the rate of return on investment depends on the cost of thermal energy for heating and the dynamics 
of its change over time, that is, the growth of tariffs for thermal energy.

The calculations reflect such indicators as: the dynamics of growth of tariffs for heat energy and the interest rate at which the discounting of future cash flows, accumulated as a result of the implementation of this energy saving measure, is estimated.

In the suggested model, it is proposed to make a calculation taking into account the refinancing rate, which, according to the National Bank of the Republic of Kazakhstan for 2020, is $9.5 \%$.

If the owners use the funds, accumulated on the current account, then the payback period with and without installation will be 13.4 and 13.3 years, respectively.

When considering the option of financing from borrowed funds, it should also be borne in mind that the money saved in subsequent years should be calculated based on the real value of money in $n$ years, i.e. future cash flows must be discounted. In this case, the formula for calculating the payback period should reflect the payback period of the considered renovation option, considering the total capital costs for its implementation, loan payments, the increase in the cost of heat energy tariffs, discounting of future cash flows achieved through savings as a result of the implementation of this energy-saving measure.

Since it is currently impossible to accurately predict how these variables will change over time in the future, only a few possible scenarios can be constructed to solve the problem of estimating the projected payback period for energy saving investments.

There are also several cases when considering the use of borrowed funds:

- firstly, the possibility of obtaining a commercial loan from a second-tier bank;

- secondly, the possibility of obtaining a loan on a subsidized basis under government programs.

In either case, we will calculate the payback period with and without installation of a heat meter.

In case that borrowed funds are used for renovation, the total investment is considered as annuity payments. In this instant, loan payments and utility bills for heating are made monthly, which makes it possible to bring the calculation formula to the calculation of the period of permanent postnumerando rent with an equal number of charges $m$ and the number of payments $p$.

The payback period for the option of obtaining a loan from a second-tier bank for a period of 3 years, with an interest rate of $20.5 \%$ per annum, without installing a heater, taking into account an increase in tariffs by an average of $18 \%$, will be 16.2 years.

When calculating the payback period for the option of obtaining a loan from a second-tier bank for a period of 3 years with an interest rate of $20.5 \%$ per annum, with the installation of a heater, it will be 15.96 years.

The payback period for the option of obtaining a subsidized loan under government programs in the amount of $6 \%$ per annum for a period of three years, with the same interest rate on the loan of $20.5 \%$ per annum, without installing a heat meter. Thus, the calculation will be made at a rate of $14.5 \%$ per annum.
The payback period with the same increase in tariffs and refinancing rates is 15.4 years. The payback period for the option of obtaining a subsidized loan under state programs in the amount of $6 \%$ per annum for a period of three years, with an interest rate on the loan of $20.5 \%$ per annum with the installation of a heating device will be 15.2 years.

Thus, taking into account the current economic and tariff situation in the Republic of Kazakhstan, the return on façade insulation investment of a 5-storeyed brick block of flats for the climatic conditions of Almaty will be no more than 16.2 years.

Based on the calculation performed, it can be concluded that with an interest rate of $14.5 \%$ per annum, NPV has a negative value, since the resulting savings per year do not cover the initial investment.

Subsequent attempts to find a discount rate that takes into account real market conditions led to the need to calculate the rate using the Fisher formula, considering the inflation rate and the average market loan rate. As a result, the discount rate should be around $25 \%$ per annum, which invariably leads to a negative NPV.

Based on the foregoing, we conclude that this investment project can be effective and have a positive NPV value only under two possible conditions:

- firstly, when the discount rate is reduced to $6 \%$ per annum;

- secondly, with the increase in tariffs of heat energy on several times.

Thus, the assumption is confirmed that the current level of tariffs for utilities is insufficient for energysaving measures and, therefore, cannot cover the costs of modernization and renovation of existing buildings and structures, and even more so cannot be attractive for companies providing energy services. Therefore, PPP (private public partnership) in the field of energy efficiency and energy saving in the housing and communal services of the Republic of Kazakhstan is necessary, since only with the support of the government can a reduction in borrowing rates and establish preferential lending conditions.

The legislative requirements for the energy efficiency of buildings and structures built before $2000 \mathrm{it}$ is necessary to tighten. Government is necessary to develop and implement monitoring mechanisms for compliance with modern building codes and regulations in the field of energy efficiency through the mandatory implementation of the building's energy passport.

Also, building and apartment metering of heat energy is required to introduce electronic systems in order to reduce the payment for utility services for heating and the transition from paying for the amount of heated area to a differentiated system for metering heat consumption.

\section{Conclusions}

At the present stage, there is a significant pool of financial instruments that can stimulate the growth of energy efficiency indicators by industry. The study examined solutions and measures, especially in terms of identifying optimal conditions that can contribute to 
improving the energy efficiency of buildings. An important result of the use of financial instruments is that the responsible government authorities must shape the energy conservation policy.

As a result of the study, a set of energy-saving measures has been developed to improve the energy efficiency of existing residential buildings, aimed at additional insulation of facades. Methods for determining the payback period and the amount of savings from energy-saving measures for existing buildings constructed and commissioned before 2000 have been proposed based on the data, obtained during the implementation of energy-saving measures.

Based on the calculation of the building energy passport, the recommended payback period for the thermal insulation of a building has been calculated, which is no more than 16.2 years for the climatic conditions of Almaty.

Using the modeling of the proposed measures, it can be concluded that the suggested system can objectively evaluate not only the available data for specific objects, but also offer specific recommendations for increasing the efficiency class, taking into account modern energy standards.

The following tasks have been solved in research:

- firstly, the theoretical aspects and main directions of energy saving and energy efficiency of residential buildings have been considered; the relevance of the issue under consideration has been determined; international experience in solving the issues of assessing the economic efficiency of energy saving measures has been explored; the process of housing repair has also been analyzed.

- secondly, the practical aspects of the current state of energy efficiency of the housing and communal services of the Republic of Kazakhstan have been analyzed.

- thirdly, methods for determining energy efficiency have been analyzed and a methodology for assessing economic efficiency of energy saving measures in residential buildings has been proposed, and the calculation of the payback period of measures for renovating external structures of a residential building has been presented.

Among the recommendations for improving energy efficiency in Kazakhstan, we propose the following financial measures:

- creation of revolving funds for energy saving and business development of energy service companies. Energy service contracts are considered popular financial assets in the world when potential investors can earn significant financial resources from participating in energy efficiency projects. They are widely used in Russia, Ukraine and Belarus;

- an interesting tool could be the creation of a "green" bank that finances energy efficient projects by accumulating funds from international and Kazakhstani financial development institutions;

- green bonds are promising instruments, which can tie up debt capital markets through investment in energy and other sectors that generate energy efficiency in industry and utilities, and provide environmental benefits;
- development of standardized banking products to finance energy efficiency programs;

- subsidizing the development of energy efficiency programs.

\section{Acknowledgements}

This paper is results by funding Committee of science Ministry of education and science of the Republic of Kazakhstan (AP05131192).

\section{References}

[1] C. Araújo, M. Almeida, L. Bragança, J.A. Barbosa, Cost-benefit analysis method for building solutions, Appl. Energy 173, 124-133 (2016)

[2] F. Ascione, N. Bianco, C. De Stasio, G.M. Mauro, G.P. Vanoli, Ulti-stage and multi-objective optimization for energy retrofitting a developed hospital reference building: A new approach to assess cost-optimality, Appl. Energy 174, 37-68 (2016)

[3] B. Atanasiu, I. Kouloumpi, Implementing the costoptimal methodology in EU countries [Electronic resource], Lessons learned from three case studies (2013) Available at: http://bpie.eu/wpcontent/uploads/2015/10/Implementing_Cost_Opti mality.pdf

[4] I. Ballarini, V. Corrado, F. Madonna, S. Paduos, F. Ravasio, Energy refurbishment of the Italian residential building stock: Energy and cost analysis through the application of the building typology, Energy Policy 105, 148-160 (2017)

[5] C. Becchio, D.G. Ferrando, E. Fregonara, N. Milani, C. Quercia, V. Serra, The Cost-optimal Methodology for Evaluating the Energy Retrofit of an ex-industrial Building in Turin, Energy Procedia 78, 1039-1044 (2015)

[6] M. Hamdy, K. Siren, S. Attia, Impact of financial assumptions on the cost-optimality towards nearly zero energy buildings-A case study, Energy Build 153, 421-438 (2017)

[7] A. Enseling, T. Loga, Implementing the costoptimal methodology in EU countries [Electronic resource], Case study Germany (2013) Available at: http://bpie.eu/wpcontent/uploads/2015/10/BPIE_Cost_Optimality_G ermany_Case_Study.pdf

[8] K. Leutgöb, J. Rammerstorfer, Implementing the cost-optimal methodology in EU countries [Electronic resource], Case study Austria (2013) Available at: http://bpie.eu/wpcontent/uploads/2015/10/BPIE_Cost_Optimality_A ustria_Case_Study.pdf

[9] J. Ortiz; A.F. Casas, J. Salom, N. Garrido Soriano, P.F. Casas, Cost-effective analysis for selecting energy efficiency measures for refurbishment of residential buildings in Catalonia, Energy Build 128, 442-457 (2016) 
[10]E. Pikas, J. Kurnitski, R. Liias, M. Thalfeldt, Quantification of economic benefits of renovation of apartment buildings as a basis for cost-optimal 2030 energy efficiency strategies, Energy Build 86, 151$160(2015)$

[11] S.F. Tadeu, R.F. Alexandre, A.J.B. Tadeu, C.H. Antunes, N.A.V. Simões, P.P. da Silva, A comparison between cost-optimality and return on investment for energy retrofit in buildings-A real options perspective, Sustain, Cities Soc. 21, 12-25 (2016)

[12]L.N. Danilevsky, Analysis of the economic efficiency of different technical solutions to improve the energy efficiency of various types of buildings [Electronic resource] (2013) Available at: http://energoeffekt.gov.by/effbuild/download/77.pdf

[13] O.V. Maksimchuk, M.V. Polyanichko, Comparative analysis of methodological approaches to assessing the effectiveness of energy-saving technologies and measures: regional aspect [Electronic resource], Regional Economics and Management 4, 52 (2017) Available at: https://eee-region.ru/article/5221/

[14] O.S. Golubova, Analysis of the economic efficiency of various technical solutions and practices that are currently widely used in the housing construction sector with an emphasis on various types of residential buildings, Minsk (2016)

[15] On the housing stock of the Republic of Kazakhstan in 2016, Statistical collection in Kazakh and Russian languages, Astana (2017)

[16] A.S. Gorshkov, A.A. Romanov, P.P. Rymkevich, Methodology for calculating the predicted payback period of energy-saving measures for the insulation of buildings, Technical and technological problems of service 4, 30, 68-74 (2014) 